\title{
RNA-expression of adrenomedullin is increased in patients with severe COVID-19
}

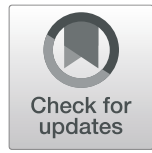

Julian Hupf $^{f^{* \dagger}}$ (D) Julian Mustroph ${ }^{2 \dagger}$, Frank Hanses ${ }^{1,3}$, Katja Evert ${ }^{4}$, Lars S. Maier ${ }^{2+}$ and Carsten G. Jungbauer ${ }^{2 \dagger}$

Adrenomedullin (ADM) is a peptide hormone with vasodilatory effects and involved in the regulation of the endothelial barrier function. Previous research found increased ADM plasma levels in patients with sepsis and ADM levels correlated with disease severity and mortality in sepsis [1]. Although severe coronavirus disease (COVID-19) shares some clinical features of sepsis (e.g., endothelial barrier dysfunction [2]), it is not known whether pathophysiological pathways of COVID-19 resemble those of sepsis [2, 3]. To our knowledge, this is the first study to evaluate ADM in context of COVID-19 [4].

We present here data regarding ADM in patients with COVID-19. Starting from March 2020, we included 45 adult patients presenting with signs of respiratory infection (cough and/or fever) to the Emergency Department in this ongoing study. The study was approved by the ethics committee of the University of Regensburg. Each individual provided written informed consent prior to inclusion. SARS$\mathrm{CoV}-2$ infection status was evaluated by PCR analysis mainly using throat rinse water (or less frequently nasopharyngeal swabs). Patients were classified as COVID-19 positive (PCR positive for SARS-CoV-2 and signs of respiratory infection) or control (other viral or bacterial respiratory infection). Whole blood was drawn by venipuncture and lysed in Trifast (Ambion) buffer solution. Further, RNA expression analysis of ADM in whole blood was performed using qPCR and normalized to GAPDH as housekeeper

\footnotetext{
* Correspondence: julian.hupf@ukr.de

${ }^{\dagger}$ Julian Hupf and Julian Mustroph contributed equally to this publication as first authors

${ }^{\dagger}$ Lars S. Maier and Carsten G. Jungbauer contributed equally to this publication as last authors

${ }^{1}$ Emergency Department, University Hospital Regensburg,

Franz-Josef-Strauß-Allee 11, 93053 Regensburg, Germany

Full list of author information is available at the end of the article
}

gene. The final diagnosis after patient discharge was reviewed by a consultant physician and patients without evidence of respiratory infection were excluded from analysis $(n=5)$.

Baseline characteristics of the study population are described in Table 1. The risk of clinical deterioration estimated by NEWS-2 Score [5] did not differ between both groups. Six patients in the COVID-19 group were admitted to the ICU (defined as "severe COVID-19"), four of them required mechanical ventilation during hospital stay and three of them died due to COVID-19 or related complications. In contrast, only one patient in the control group died from pneumonia.

ADM expression was significantly elevated in patients with COVID-19 than other respiratory infections (Fig. 1a) despite similar clinical features at admission. In patients with COVID-19, ADM expression was significantly higher in patients with severe COVID-19 than in patients with less severe COVID19 (Fig. 1b). Further, ADM expression was not significantly different between patients with less severe COVID-19 and patients with other respiratory infections than COVID-19 ( $p=$ n.s.). According to ROCanalysis, ADM was able to differentiate severe from non-severe COVID-19 cases with an AUC of 0.82 $(p=0.024,95 \%$ CI $0.64-1.0)$.

To strengthen our hypothesis, we analyzed ADM expression in the left ventricular myocardial tissue of patients who were deceased from COVID-19. Infection with SARS-CoV-2 had been verified by PCR in all of these patients. As control, we used a combination of left ventricular myocardial tissue of patients who died from other respiratory infections or from patients destined for organ donation, which could ultimately not be performed. We found a significantly elevated expression of ADM in patients who died from COVID-19 in contrast to controls (Fig. 1c). 
Table 1 Baseline characteristics of the study population

\begin{tabular}{|c|c|c|c|}
\hline & COVID-19 & Controls & \\
\hline$n$ & 21 & 19 & \\
\hline Sex male & $57.1 \%$ & $57.9 \%$ & $p=$ n.s. ${ }^{*}$ \\
\hline $\mathrm{Age}^{\mathrm{a}}$ & $50 \pm 16$ & $56 \pm 20$ & $p=$ n.s.\# \\
\hline ICU admission & $28.6 \%$ & $5.3 \%$ & $p=$ n.s. ${ }^{*}$ \\
\hline Death & $19.0 \%$ & $5.3 \%$ & $p=$ n.s. ${ }^{*}$ \\
\hline Coronary artery disease & $4.8 \%$ & $36.8 \%$ & $p=0.02^{*}$ \\
\hline Chronic heart failure & $4.8 \%$ & $15.8 \%$ & $p=$ n.s. ${ }^{*}$ \\
\hline Chronic obstructive pulmonary disease & $0.0 \%$ & $21.1 \%$ & $p=0.04^{*}$ \\
\hline Hypertension & $28.6 \%$ & $47.4 \%$ & $p=$ n.s. ${ }^{*}$ \\
\hline Hyperlipidemia & $9.5 \%$ & $36.8 \%$ & $p=$ n.s. ${ }^{*}$ \\
\hline Diabetes & $4.8 \%$ & $26.3 \%$ & $p=$ n.s. ${ }^{*}$ \\
\hline Chronic renal failure & $9.5 \%$ & $21.1 \%$ & $p=$ n.s. ${ }^{*}$ \\
\hline Heart frequency $[b p m]^{a}$ & $96 \pm 15$ & $92 \pm 27$ & $p=$ n.s.\# \\
\hline Systolic blood pressure $[\mathrm{mmHg}]^{a}$ & $132 \pm 20$ & $134 \pm 28$ & $p=$ n.s.\# \\
\hline Oxygen saturation ${ }^{a}$ & $95 \pm 4 \%$ & $95 \pm 3 \%$ & $p=$ n.s.\# \\
\hline Respiratory rate [per minute] ${ }^{a}$ & $22 \pm 7$ & $21 \pm 7$ & $p=$ n.s.\# \\
\hline Temperature $\left[{ }^{\circ} \mathrm{C}\right]^{\mathrm{a}}$ & $37.7 \pm 0.7$ & $37.4 \pm 0.9$ & $p=$ n.s.\# \\
\hline$B M l^{\mathrm{a}}$ & $27.8 \pm 5.6$ & $27.6 \pm 5.3$ & $p=$ n.s. $\#$ \\
\hline NEWS-2 Score ${ }^{\mathrm{b}}$ & $4 \pm 5$ & $3 \pm 4$ & $p=$ n.s.\# \\
\hline Creatinine $[\mathrm{mg} / \mathrm{dl}]^{\mathrm{b}}$ & $0.88 \pm 0.58$ & $0.95 \pm 0.55$ & $p=$ n.s. $\#$ \\
\hline $\mathrm{CRP}\left[\mathrm{mg} / \mathrm{l}^{\mathrm{b}}\right.$ & $43.4 \pm 66.7$ & $48.4 \pm 74.0$ & $p=$ n.s.\# \\
\hline WBC [/nll $]^{b}$ & $7.2 \pm 4.7$ & $8.1 \pm 7.9$ & $p=$ n.s.\# \\
\hline IL-6 [pg/m/ $]^{\mathrm{b}}$ & $30.7 \pm 50.1$ & $35.8 \pm 87.5$ & $p=$ n.s.\# \\
\hline ADM/GAPDH expression ${ }^{a}$ & $0.88 \pm 0.45$ & $0.58 \pm 0.35$ & $p=0.025$ \\
\hline
\end{tabular}

*Tested with Fisher's exact test

${ }^{\#}$ Tested with Mann-Whitney $U$ test

a Values are mean \pm standard deviation

${ }^{\text {b } V a l u e s}$ are median \pm interquartile range

\section{Whole blood RNA expression}

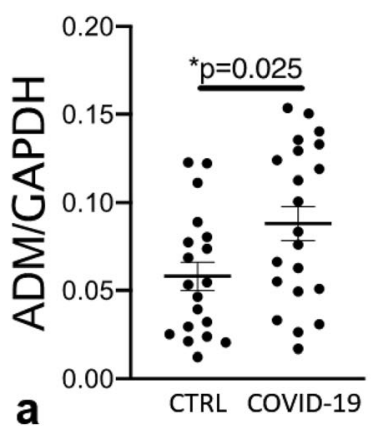

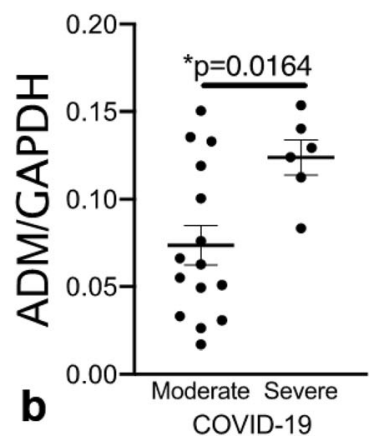

\section{Cardiac tissue RNA} expression

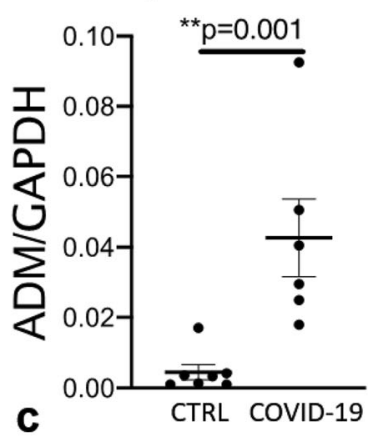

Fig. 1 Adrenomedullin RNA expression in whole blood is significantly increased in patients with COVID-19 versus other respiratory infections ("CTRL") in whole blood (a, Student's $t$ test). Further, ADM is significantly elevated in patients with severe COVID-19 in contrast to moderate disease (b, Student's $t$ test). ADM expression in myocardial tissue is increased in patients, who died from COVID-19, in comparison to controls ("CTRL", c, Mann-Whitney U test). Values are depicted as mean and standard error of the mean 
Our findings suggest a potential role for ADM in severe COVID-19. While ADM might be a therapeutic target in sepsis and septic shock, further research is needed regarding ADM in COVID-19. Further, the diagnostic potential of ADM as a marker for progression to severe COVID-19 at first medical contact should be evaluated.

Limitations of this study are the small number of patients included and RNA expression analysis in contrast to direct measurement of ADM levels. This study, however, is the first to show an association between ADM and severity of COVID-19.

\section{Acknowledgements}

We acknowledge Christine Meindl, Ute Hubauer, Gabriela Pietrzyk, Simon Leininger, Stephan Staudner, Manuel Vogel, Stefan Wallner, Markus

Zimmermann, Teresa Stauber, and Sebastian Benkhoff for their contribution to this study.

\section{Authors' contributions}

$\mathrm{JH}$ and $\mathrm{JM}$ contributed equally to this work. $\mathrm{JM}, \mathrm{JH}$, and $\mathrm{CJ}$ designed the study, gathered and analyzed data, performed statistical analysis, wrote the manuscript, and are responsible for the integrity of the work as a whole. FH and KE gathered data and revised the manuscript for critical intellectual content. LSM analyzed data and revised the manuscript for critical intellectual content. All authors read and approved the final manuscript.

\section{Funding}

This study was supported by the German Cardiac Society Clinician Scientist program to Julian Mustroph, DFG grant Ma1982/5-1, SFB 1350 TPA6 and the University of Regensburg ReForM C program. Open access funding provided by Projekt DEAL.

\section{Availability of data and materials}

The datasets used and/or analyzed during the current study are available from the corresponding author on reasonable request.

\section{Ethics approval and consent to participate}

The study was approved by the ethics committee of the University of Regensburg, Regensburg, Germany. Informed consent was obtained from each individual previous to study inclusion, who participated in the wholeblood RNA expression study.

\section{Consent for publication}

Not applicable.

\section{Competing interests}

The authors declare that they have no competing interests.

\section{Author details}

'Emergency Department, University Hospital Regensburg, Franz-Josef-Strauß-Allee 11, 93053 Regensburg, Germany. ${ }^{2}$ Department of Internal Medicine II (Cardiology), University Hospital Regensburg, Franz-Josef-Strauß-Allee 11, 93053 Regensburg, Germany. ${ }^{3}$ Department of Infection Prevention and Infectious Diseases, University Hospital Regensburg, Franz-Josef-Strauß-Allee 11, 93053 Regensburg, Germany. ${ }^{4}$ Institute of Pathology, University of Regensburg, Franz-Josef-Strauß-Allee 11, 93053 Regensburg, Germany.

Received: 3 August 2020 Accepted: 12 August 2020

Published online: 28 August 2020

\section{References}

1. Geven C, Kox M, Pickkers P. Adrenomedullin and Adrenomedullin-targeted therapy as treatment strategies relevant for sepsis. Front Immunol. 2018;9: 292. https://doi.org/10.3389/fimmu.2018.00292 .
2. Pons S, Fodil S, Azoulay E, Zafrani L. The vascular endothelium: the cornerstone of organ dysfunction in severe SARS-CoV-2 infection. Crit Care. 2020;24:307. https://doi.org/10.1186/s13054-020-03062-7

3. Li H, Liu L, Zhang D, Xu J, Dai H, Tang N, et al. SARS-CoV-2 and viral sepsis: observations and hypotheses. Lancet. 2020;395:1517-20. https:/doi.org/10. 1016/S0140-6736(20)30920-X .

4. Wilson DC, Schefold JC, Baldirà J, Spinetti T, Saeed K, Elke G. Adrenomedullin in COVID-19 induced endotheliitis. Crit Care. 2020;24:411. https://doi.org/10.1186/s13054-020-03151-7.

5. Royal College of Physicians. National Early Warning Score (NEWS) 2: Standardising the assessment of acute-illness severity in the NHS. Updated report of a working party. RCP. 2017. https://www.rcplondon.ac.uk/projects/ outputs/national-early-warning-score-news-2.

\section{Publisher's Note}

Springer Nature remains neutral with regard to jurisdictional claims in published maps and institutional affiliations.

Ready to submit your research? Choose BMC and benefit from:

- fast, convenient online submission

- thorough peer review by experienced researchers in your field

- rapid publication on acceptance

- support for research data, including large and complex data types

- gold Open Access which fosters wider collaboration and increased citations

- maximum visibility for your research: over $100 \mathrm{M}$ website views per year

At $\mathrm{BMC}$, research is always in progress.

Learn more biomedcentral.com/submissions 